\title{
Landslide susceptibility assessment in the Peloritani Mts. (Sicily, Italy) and clues for tectonic control of relief processes
}

\author{
G. De Guidi and S. Scudero \\ University of Catania, Department of Biological, Geological and Environmental Sciences, Earth Science Section, \\ Corso Italia 57, 95129, Catania, Italy \\ Correspondence to: G. De Guidi (deguidi@unict.it) \\ Received: 4 June 2012 - Published in Nat. Hazards Earth Syst. Sci. Discuss.: - \\ Revised: 19 November 2012 - Accepted: 21 November 2012 - Published: 18 April 2013
}

\begin{abstract}
Many destructive shallow landslides hit villages in the Peloritani Mountains area (Sicily, Italy) on 1 October 2009 after heavy rainfall. The collection of several types of spatial data, together with a landslide inventory, allows the assessment of the landslide susceptibility by applying a statistical technique. The susceptibility model was validated by performing an analysis in a test area using independent landslide information, the results being able to correctly predict more than $70 \%$ of the landslides.

Furthermore, the susceptibility analysis allowed the identification of which combinations of classes, within the different factors, have greater relevance in slope instability, and afterwards associating the most unstable combinations (with a short-medium term incidence) with the endogenic processes acting in the area (huge regional uplift, fault activity). Geological and tectonic history are believed to be key to interpreting morphological processes and landscape evolution. Recent tectonic activity was found to be a very important controlling factor in landscape evolution. A geomorphological model of cyclical relief evolution is proposed in which endogenic processes are directly linked to superficial processes.

The results are relevant both to risk reduction and the understanding of active geological dynamics.
\end{abstract}

\section{Introduction}

Shallow landslides are very common in steep mountainous regions where they often constitute a major risk factor for human activities (Glade, 1998; Singh et al., 2005; Claessens et al., 2007; Salciarini et al., 2008; Gullà et al., 2008; Deb and El-Kadi, 2009; Harp et al., 2009). Their occurrence, often triggered by exceptional rainfall or earthquakes, can involve large regions with a huge numbers of events. The simultaneous occurrence of multiple landslides gives the exclusive opportunity to study their distribution in relation to several environmental factors.

On 1 October 2009, more than one thousand shallow landslides occurred in the NE corner of Sicily (Italy) (Maugeri and Motta, 2010). The affected area extended over approximately $30 \mathrm{~km}^{2}$ and was located on the eastern sector side of the Peloritani mountain ridge. Slope instabilities were triggered by heavy rainfall and affected mainly the lower parts of 14 small catchments directly facing the Ionian Sea (Fig. 1). Landslides caused 35 fatalities, the total devastation of several villages in Messina province, and severe damage to the public heritage and the local economy (Fig. 2). Rainfall was very intense: $223 \mathrm{~mm}$ of rain fell in $7 \mathrm{~h}$, with a peak of $10.6 \mathrm{~mm}$ in $5 \mathrm{~min}$, on terrain already saturated by precipitation during previous weeks ( $\sim 400 \mathrm{~mm}$ in 14 days) (Maugeri and Motta, 2010).

Here we perform a susceptibility analysis for shallow landslides, by spatial combination of the inventory map of the events with some causative factors. We employ a statistical bivariate method that assigns numerical weight values to each class of causative factors.

The susceptibility assessment yields two main results. Firstly, we are able to identify reliably which areas in this territory are more likely to be involved in future landslides. Secondly, we can investigate the connection between the most landslide-prone conditions and the active geodynamics of the area.

The principal thesis is that geotectonic history is behind the factors controlling landsliding, playing a leading role in 


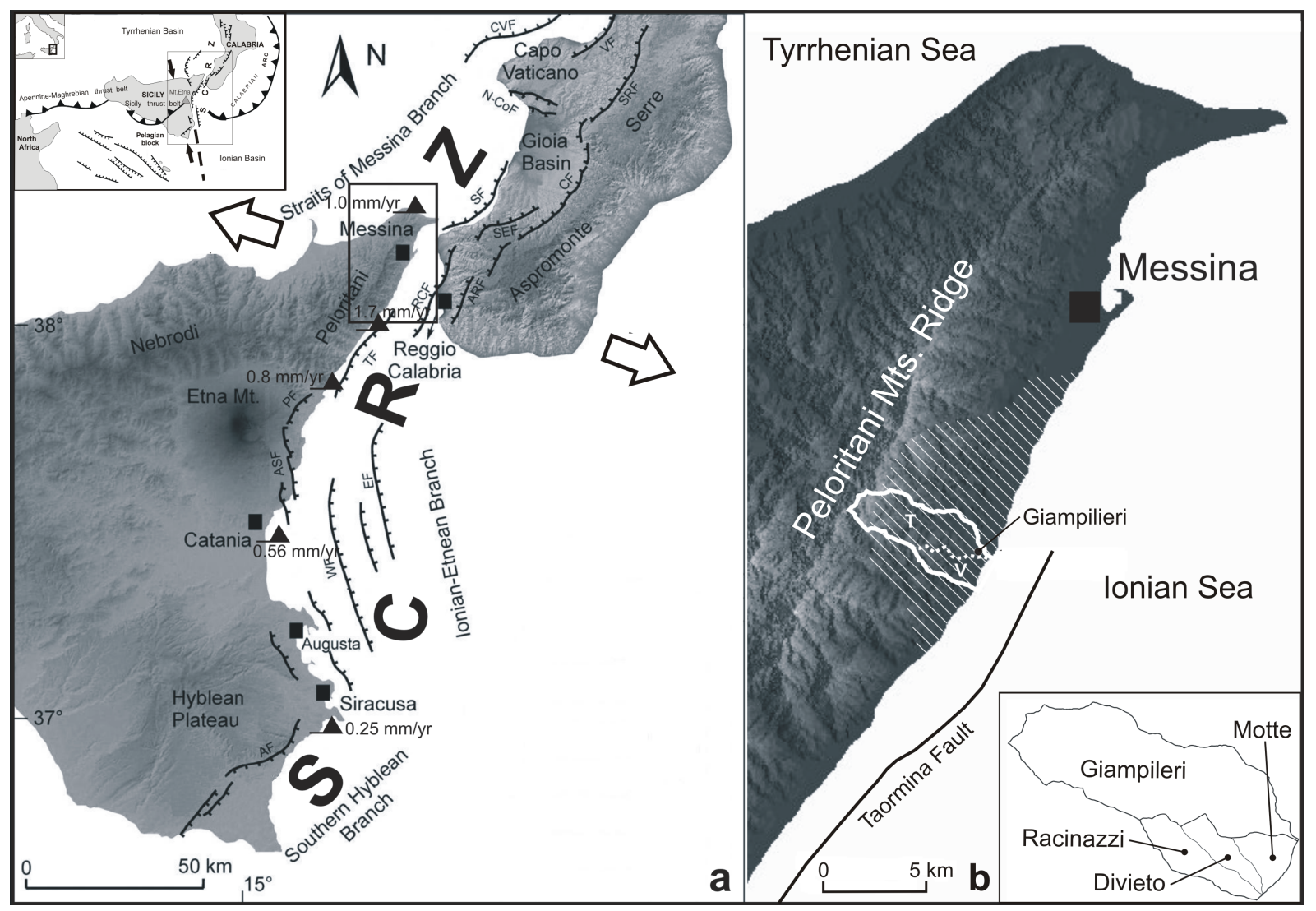

Fig. 1. (a) Tectonic map of eastern Sicily and southern Calabria showing the Siculo-Calabrian Rift Zone (SCRZ), modified from Catalano et al. (2008). Arrows indicate the regional extension direction and triangles the uplift rates given by Catalano et al. (2003) and Catalano and De Guidi (2003); RIF: Rosolini-Ispica faults; AV: Avola fault; WF: western Ionian fault; EF: eastern Ionian fault; ASF: Acireale-S.Alfio faults; PF: Piedimonte fault; TF: Taormina fault; RCF: Reggio Calabria fault; AF: Armo fault; SF: Scilla fault; SEF: S.Eufemia fault; CF: Cittanova fault; SRF: Serre fault; VF: Vibo fault; CVF: Capo Vaticano fault; N-CoF: Nicotera-Coccorino faults. (b) the hatched zone represents the area affected by landslides on the 1st October 2009; the continuous white line indicates the study area; training area (T) and validation area $(\mathrm{V})$ of the landslide susceptibility analysis are showed.

the slow but inexorable process of transformation of the morphological structure of this area. In fact eastern Sicily and southern Calabria are among the most tectonically active areas in the Mediterranean. Since the Middle Pleistocene, the entire Calabrian arc has undergone strong tectonic uplift (Montenat et al., 1991; Westaway, 1993; Tortorici et al., 1995; Rust and Kershaw, 2000), accompanied by activity of a normal fault belt since $700 \mathrm{ka}$ BP (Fig. 1). Present-day activity is testified by the strong historical seismicity (Monaco et al., 1997; Monaco and Tortorici, 2000; Catalano et al., 2008).

Several papers have highlighted the relationship between tectonics and the evolving landscape (Burbank and Pinter, 1999 and reference therein; Montgomery and Brandon, 2002; Snyder et al., 2002, 2003; Korup et al., 2007; Agliardi et al., 2009; Goswami et al., 2011). Similarly, we investigate the role of tectonics on surface processes with respect to geological, climatic and environmental factors.

\section{Morphostructural setting}

The study area is part of the Peloritani mountain range belonging geologically to the Calabrian arc and representing the inner chain of the Apennine-Maghrebian mountain belt (Amodio Morelli et al., 1976; Bonardi et al., 1982). The mountain ridge extends longitudinally for about $50 \mathrm{~km}$, with a SW-NE orientation (Fig. 1), resulting in peaks higher than $1200 \mathrm{~m}$ that shelve toward the Tyrrhenian and Ionian seas (NW and E respectively).

\subsection{Tectonic outline}

The Calabrian arc has a long and complex geological history. In fact, it has been involved in two orogenic cycles since late Palaeozoic times and many other Neogene deformation events. More recently (Middle Pleistocene), the entire Calabrian arc underwent strong tectonic uplift (Montenat et al., 1991; Westaway, 1993; Tortorici et al., 1995), with rates greater than $1.0 \mathrm{~mm} \mathrm{yr}^{-1}$, accompanied since $700 \mathrm{ka}$ 

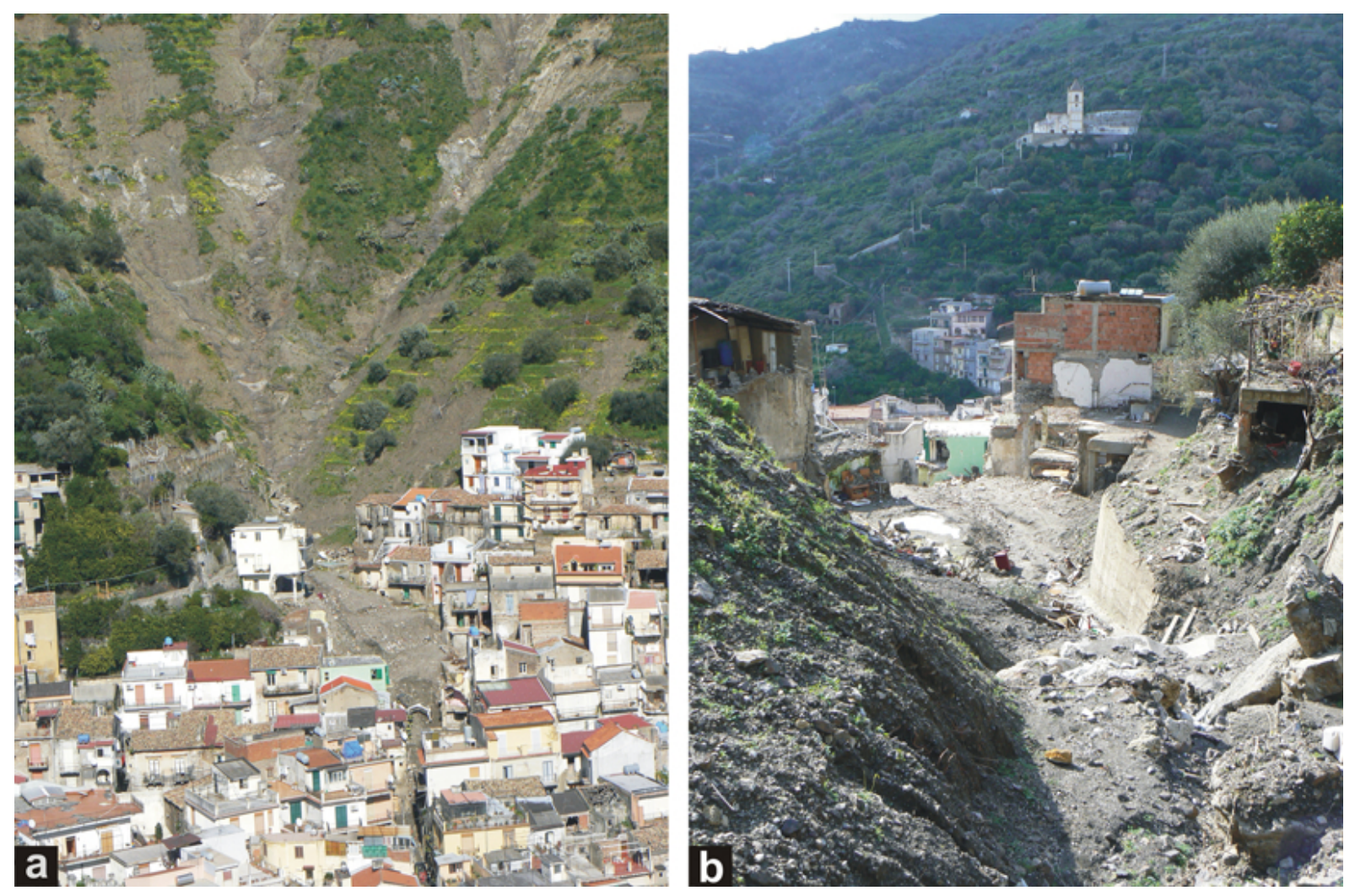

Fig. 2. Examples of some shallow landslides triggered by October 1st 2009 rainfall event in Giampilieri village: (a) front view; (b) downslope view.

by the activity of a normal fault system called the SiculoCalabrian Rift Zone (SCRZ) (Monaco et al., 1997; Monaco and Tortorici, 2000; Catalano et al., 2008) (Fig. 1). The corresponding regional tensional stress is oriented $N \sim 115 \mathrm{E}$ (D'Agostino and Selvaggi, 2004; Catalano et al., 2008) and is partially accommodated by deformation on the various fault segments. The study area is located at the footwall of one of these active normal faults (Taormina fault) (De Guidi et al., 2003). Taking into account the vertical deformation induced by its activity, the total tectonic uplift rate for the last $125 \mathrm{ka}$ reaches a maximum value of $1.7 \mathrm{~mm} \mathrm{yr}^{-1}$ (Catalano and De Guidi, 2003; Catalano et al., 2003) across all of eastern Sicily.

Holocene uplift rates are even greater, and, in fact, this is one of the areas that incurred the highest uplift in this period for the entire Italian peninsula (Lambeck et al., 2004). Vertical rates measured in the area of the Peloritani Mts. peak at between 1.4 and $2.4 \mathrm{~mm} \mathrm{yr}^{-1}$ for the last $5000-6000 \mathrm{yr}$ (Stewart et al., 1997; Rust and Kershaw, 2000; Antonioli et al., 2003; De Guidi et al., 2003; Antonioli et al., 2009), although the true uplift with respect to base level (Ionian Sea level) is lower, because in the same period sea level rose at an average rate of about $1 \mathrm{~mm} \mathrm{yr}^{-1}$ (Lambeck et al., 2004). However, the increase in the topographic gradient of the Peloritani Mts. is very notable.

\subsection{Morphological features}

The landscape of the Peloritani Mts. reflects the tectonic setting of the area, in particular the intense recent dynamics. Vertical movements of base level during the late Quaternary, caused by interaction between vertical tectonic deformation and eustatic sea level changes, controlled the shaping of the landforms. This resulted in a poly-cyclical evolution of the coastal slopes that shows imprinting of many sequential cycles of rejuvenation during Late Pleistocene and Holocene times (Montenat et al., 1991; Rust and Kershaw, 2000; Catalano and De Guidi, 2003; Catalano et al., 2003; De Guidi et al., 2003).

One of the most prominent aspects is represented by a consequent drainage system, developed on both the northwestern and eastern slopes of the Peloritani mountain ridge. Other morphological features are represented by the remnants of marine terraces located at various elevations on the coastal slopes, and deep V-shaped valleys, typical of recent erosional stage, which cut pre-existing peneplaned surfaces.

In particular, different fluvial landforms characterize the northwestern and eastern sectors of the Peloritani Mts. In the former, low-energy fluvial landforms mark the landscape; river valleys with smooth longitudinal profiles separate wide north-south elongated surfaces dipping toward 

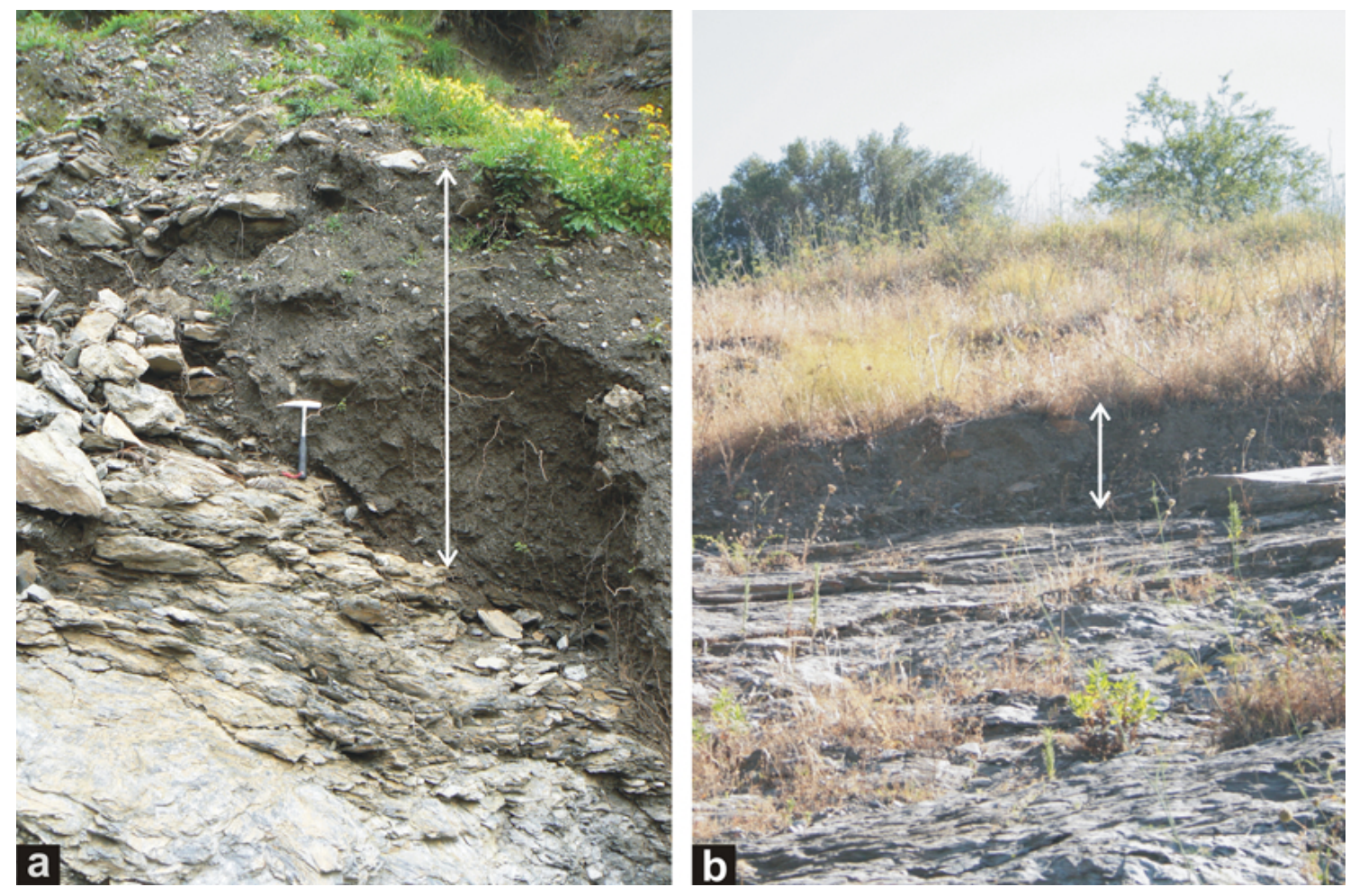

Fig. 3. Landslides scars: lateral (a) and frontal (b) view. Note the sharp contact between the colluvium (approximately $1.0 \mathrm{~m}$ thick) and the bedrock.

the Tyrrhenian Sea. In the latter the landscape exhibits more the results of its poly-cyclical evolution: deeply incised valleys separate interfluves constituted by remnants of marine terrace surfaces (APAT, 2008 and 2010). The longitudinalprofiles show several steady knickpoints due to stages of relative stability of the base level (Goswami et al., 2012). The most recent knickpoint is active and steadily migrates upslope while the steep flanks of the river valleys are affected by headward erosion.

Several streams characterized by high gradient and short length, fed by intermittent and torrential rainfall, drain the Peloritani Mts., in particular the eastern (i.e. Ionian) sector. The local name for this kind of river is fiumara. The precipitation regime controls their activity, and therefore sudden, heavy floods usually interrupt longer period of inactivity. The morphostructural framework also influences flow regime, with active tectonic uplift being one of the main controlling features (Sabato and Tropeano, 2004).

The overall topography is uneven with steep slopes ranging between $25^{\circ}$ and $70^{\circ}$, but flat areas may also occur where remnants of Quaternary marine terraces are preserved; they originated through the interplay between tectonic uplift and the sea level high stands (Catalano and De Guidi, 2003; Antonioli et al., 2006).

\section{Landslide susceptibility assessment}

The landslide susceptibility for a given landslide typology is the spatial probability that an event may occur in a given area considering a given selection of geo-environmental factors (van Westen at al., 2006; Fell et al., 2008). Susceptibility can be evaluated using many different approaches according to the aims of the susceptibility assessment itself and to the scale of the analysis. There are heuristic or empirical models, statistical analyses, deterministic models and probabilistic methods (Guzzetti et al., 1999; Brenning, 2005; van Westen et al., 2008; Cascini, 2008). Many of these have been developed in conjunction with geographic information systems (GIS) (Carrara et al., 1991; van Westen et al., 1997; Carrara et al., 1999). In particular, susceptibility assessment for shallow landslides recently has been evaluated using methods belonging to all four groups (Dai and Lee, 2003; Guzzetti et al., 2005; Singh et al, 2005; Deb and El-Kadi, 2009; Godt et al., 2008; Gullà et al., 2008; Salciarini et al., 2008; Günther and Thiel, 2009; Piacentini et al., 2012).

All of the methods entail some basic assumptions (Guzzetti et al., 1999 and references therein): (i) each landslide leaves on the terrain some features that are recognizable and can be mapped in the field or remotely; (ii) slope failures obey mechanical laws, and the collection of instability factors leading to the failures allows assessment of the susceptibility models; (iii) future landslides will occur under the 
same condition that caused past failures; (iv) it is possible to infer the spatial and temporal occurrence of failures through the analysis of the geo-environmental factors. Thus, a given territory can be classified according to different landsliding probability.

We performed the susceptibility assessment with various different statistical models, but here we present only the most effective one. The model was performed in four small catchments of the eastern sector: Giampilieri, Divieto, Racinazzi and Motte (Fig. 1). These catchments were selected because they form the core of the area of landslides, where we have at our disposal the largest amount of data (Scudero and De Guidi, 2011) The basins extend over a $\sim 13 \mathrm{~km}^{2}$ area within the eastern flank of the mountain range, directly facing the Ionian Sea. Moreover, the study area was subdivided into a "training area" where the analysis was performed, and a "validation area" where the effectiveness of the results was tested.

\subsection{Landslide characteristics and inventory}

Shallow landslides constitute the main geological hazard in the Peloritani Mts., even though some larger and more complex landslides are present. The latter are mainly induced by the downcutting of stream beds consequent to the overall rejuvenation process, but they were not considered in this study.

All of the landslides took place within the patchy layer of loose, heterogeneous and often weathered material of variable thickness (1-3 m) covering the majority of the slopes (colluvium) (Fig. 3). This deposit is characterized by a high coarse fraction (gravel content more than $50 \%$ ) and a clay content that is often scarce. Its friction angle can reach more than $35^{\circ}$, allowing the material to remain, under normal conditions, on the steep slopes of the catchments. According to Lacerda (2007), the term colluvium refers to soil material that underwent little transport or derives from large landslides with sudden transport.

The landslides are usually triggered by the detachment of small boulders from natural scarps, rocky cliffs or ancient retaining walls used for terracing the slopes for agricultural purposes, over a saturated portion of colluvium (Agnesi et al., 2009). Another mechanism is the sudden fluidification of the colluvial material due to superficial or subsuperficial water currents or temporary springs rising from the bedrock where contrasts of hydraulic properties with the colluvial layer may occur (Agnesi et al., 2009). The volume of single events is relatively constant, usually comprising between $10^{3}$ and $10^{4} \mathrm{~m}^{3}$ (Falconi et al., 2011).

The flows usually developed downslope, even though they can also enlarge laterally and migrate upslope. The material often canalized following the natural drainage, eroding and sometimes exhuming buried gullies. During their movement downwards, the flows eroded the base or the lateral edges of their channels, gaining further material and increasing their volume, until they stopped in the zone of accumulation, usually located at the foots of the slopes. The villages involved were located at the bases of large, steep slopes and were party swept away by the mobilized material.

Even though different triggering mechanisms induced the failures, all of the events shared the same general geoenvironmental arrangement at the source points before the failure occurred. Therefore, we ascribe the failure mechanism to very local conditions and we will treat the instabilities as being a unique typology.

The landslide inventory map of the Regional Civil Defence (Basile, 2010) was verified through field reconnaissance surveys and integrated with missing data to ensure accuracy in the presence and location of the landslides. A total of 397 landslides have been mapped in the entire study area.

The inventory map of Basile (2010) distinguishes, for each landslide, an area mainly characterized by erosion, and the fan, where the accumulation of transported material dominates. Within the areas experiencing loss of material, the source area and the channel have not been considered separately. For the susceptibility assessment of this type of landslide, we have to consider only the area where the first detachment originated. For this reason we considered as source areas for the shallow landslides a circle of $25 \mathrm{~m}$ in diameter comprising the initiation point and the upper part of each event (Salciarini et al., 2006). This value is congruent with the scale of our analysis (Hengl, 2006), and with the spatial variability of the causative factor observed in the field.

\subsection{Spatial variables}

Many factors can influence the occurrence of landslides, and understanding the determinant factors requires a good knowledge of the study area, of the phenomena and an assessment of the scale of analysis and the methodology (van Westen et al., 2006, 2008; Cascini, 2008). The experience gained during field activities (Scudero and De Guidi, 2011) allowed us to recognize six different controlling factors: lithology, geomechanical classification, geomorphology, distance to stream, slope angle, and aspect.

Many other geo-environmental factors have been recognized to have a role in instabilities (van Westen et al., 2008), but these have been excluded from our analysis for the following reasons: (i) if they act evenly, or almost evenly, over the entire study area; (ii) if we did not recognize their influence on landslides during field surveys; (iii) if they can be linked to other factors already taken into account. In particular we excluded any anthropogenic influences (e.g. proximity to transportation networks or buildings) since instabilities are widespread even on natural slopes, and they eventually interact with infrastructures or other anthropogenic features only during their development downslope. Factors such as drainage and lineament densities were ignored, because they are already incorporated in other indicators. 

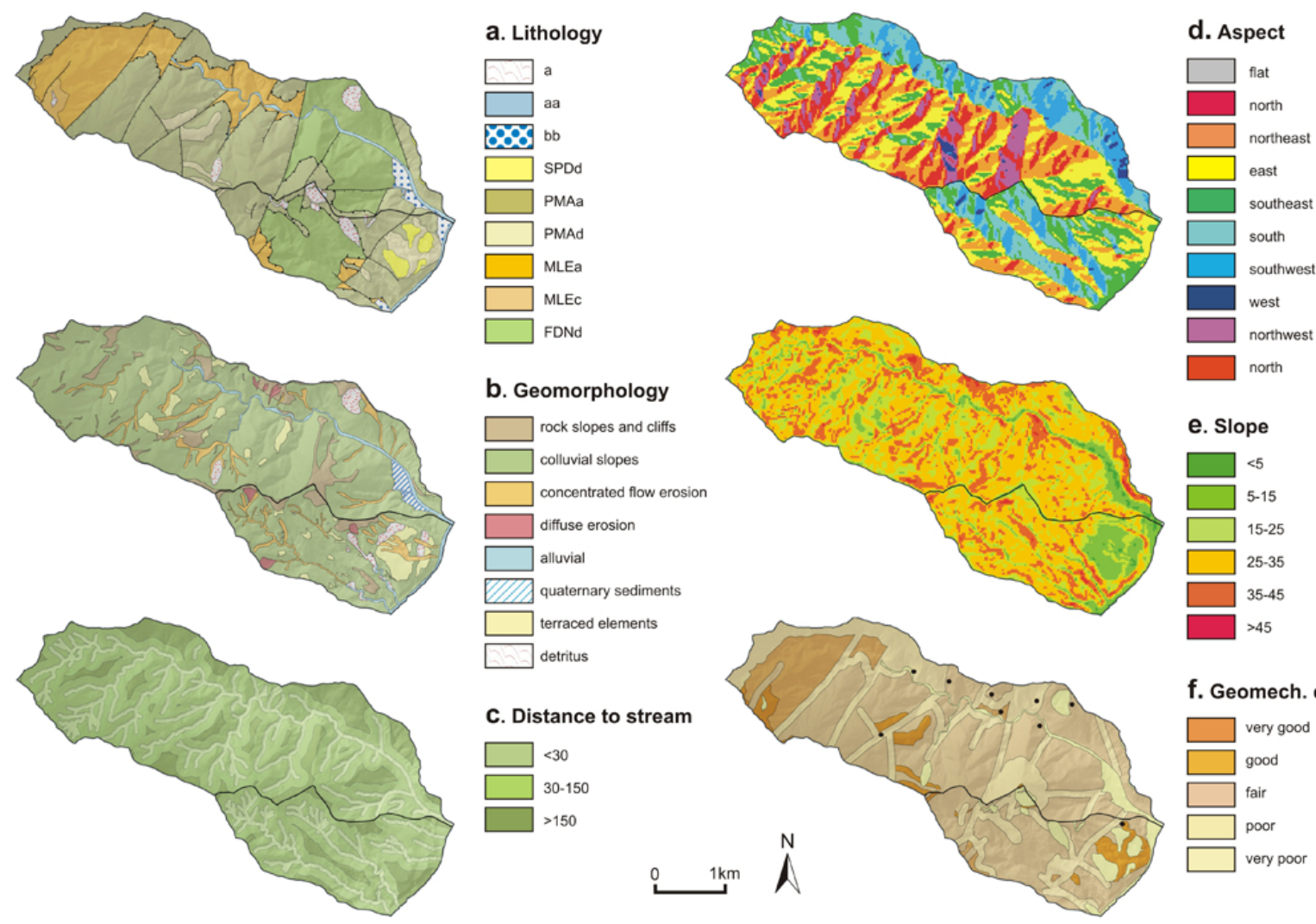

f. Geomech. class.

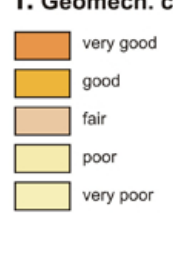

Fig. 4. Spatial distribution of the six causative factors: (a) bedrock lithology and lineaments (abbreviations from Messina-Reggio C. Geological Map, Foglio 601 Messina-Reggio C. della Carta Geologica d'Italia, scala 1:50 000. APAT, Servizio Geologico d'Italia, Dipartimento Difesa del Suolo, Roma, 2008); (a) slope deposits; aa: present-day alluvial deposits; bb: recent alluvial deposits; SPDd: calcarenites; PMAa paragneiss of the Aspromonte unit; PMAd marble of the Aspromonte unit; MLEa: mica schists of the Mela unit; MLEc: marble of the Mela unit; FDNd: phyllite of the Mandanici unit); (b): geomorphological units; (c): distance to stream; (d): aspect of the slopes; (e): slope angle (degree); (f): geomechanical classification of rock types according to the RMR proposed by Bieniawski (1979); black dots indicate the measurement stations.

We mapped the spatial distribution of the causative factors (Fig. 4) on a 1:10000 scale and acquired them as spatial layers in a G.I.S. environment with $10 \mathrm{~m} \times 10 \mathrm{~m}$ pixel resolution. This definition is accurate enough considering the map scale and the minimum dimension of the observed objects (Hengl, 2006).

The bedrock geology of the study area consists of three different types of metamorphic rock, including low-grade phyllites that are covered tectonically by higher-grade mica schist and paragneiss. These rocks represent the late Palaeozoic basement of the European plate that was thrust over the Apennine-Maghrebian chain (Giunta and Nigro, 1999; De Gregorio et al., 2003; Festa et al., 2004; Heymes et al., 2010), then deformed during the Tertiary (Monaco et al., 1996; Bonardi et al., 2002; Somma et al., 2005; Grande et al., 2009) and Quaternary (Tortorici et al., 1995; De Guidi et al., 2003; Catalano et al., 2008). Because of their geological history, the rocks are deeply fractured and weathered. We performed a geomechanical characterization of the rock masses according to the rock mass rating (RMR) proposed by Bieniawski (1979) in order to assess their quality. For this purpose we surveyed random outcrops of bedrock, representing each lithotype, and estimated the rock quality designation index (RQD), the uniaxial compressive strength, the condition of the discontinuities (spacing, roughness, persistence, filling, alteration) and groundwater condition. In particular, the uniaxial compressive strength was estimated through the Schmidt hammer readings converted according to the empirical relationship proposed by Deere and Miller (1966). The collection of other parameters followed the scheme proposed by ISRM (1981).

We noted a sharp decrease of mechanical characteristics approaching the tectonic lineaments at a distance of less than $50 \mathrm{~m}$. Therefore the localized RMR analyses were spatialized by combining rock type with distance to tectonic lineaments (Greco and Sorriso-Valvo, 2005; Borrelli et al., 2007; Pellegrino and Prestininzi, 2007).

Such subdivision provides additional information concerning differences in the rock masses and represents a 
causative factor in describing landslide occurrence (Federici et al., 2007; van Westen et al., 2008).

The geomorphological map distinguishes terrain units according to processes in action, the origin of the features, and the materials involved. The most relevant feature is the extensive presence of a colluvial layer covering the majority of the slopes. It is characterized by almost uniform thickness ( $\sim 1 \mathrm{~m}$ ) (Fig. 3), although thicker deposits, up to $3 \mathrm{~m}$, may occur on some slopes. Rock slopes, concentrated flow erosion, and areas with diffuse erosion are other representative features. More than one geomorphological process could coexist; however we considered only the most prominent process in each part of the study area.

We also generated a digital elevation model (DEM) from a 1:10 000 map with $10 \mathrm{~m}$ contour intervals and derived three topographic features: (i) slope; (ii) aspect; and (iii) distance from drainage.

Slope angle is one of the most relevant factors controlling landsliding. Steep slopes characterize the entire Peloritani ridge: the highest peaks can reach $1200 \mathrm{~m}$ a.s.l. within $5 \mathrm{~km}$ from the coast, and the mean slope angle in the study area is $32^{\circ}$.

The slope aspect can influence hydrological processes, and therefore it also has an indirect bearing on weathering, vegetation and root development. But the aspect map can also suggest which slopes are more prone to landsliding considering the spatial organization of the drainage network. In fact, in active areas it is usually controlled by tectonic processes and provides information on the state of evolution of the fluvial basin (Guarnieri and Pirrotta, 2008).

Finally, the distance from the drainage system has been considered because relief is intensely dissected by stream segments and erosion can influence the distribution of instabilities (van Westen et al., 2008).

\subsection{Susceptibility analysis and mapping}

The landslide susceptibility analysis was performed using a statistical bivariate method. Bivariate techniques have been used widely in the literature for susceptibility assessment (van Westen, 1997; Cevik and Topal, 2003; van Westen et al., 2003; Süzen and Doyuran, 2004; Yalcin, 2008, Nandi and Shakoor, 2009). Each of the spatial variables (layer) discussed in the previous paragraph was considered to be an independent variable causing landslides. In the bivariate approach each independent variable is correlated with the dependent one (landslide map), and their relationships with landslide occurrences were calculated through pairwise map crossing. Furthermore, the bivariate techniques assume that the independent variables are not inter-related and that they all have the same weight in landsliding. In particular, we performed landslide susceptibility analysis using the statistical index method proposed by van Westen (1997).

In the statistical index method, the weights of the classes of each factor are calculated as the natural logarithm of the ratio between the density of landslides in the considered class and the density of landslides for the entire map; weights were calculated using the following equation:

$$
\begin{aligned}
w_{i j} & =\ln \left(f_{i j} / f\right)=\ln \left[\left(\mathrm{A}_{i j}^{*} / \mathrm{A}_{i j}\right) *\left(\mathrm{~A} / \mathrm{A}^{*}\right)\right] \\
= & \ln \left[\left(\mathrm{A}_{i j}^{*} / \mathrm{A}^{*}\right) *\left(\mathrm{~A} / \mathrm{A}_{i j}\right)\right]
\end{aligned}
$$

where, $w_{i j}$ is the weight of the class $i$ of parameter $j, f_{i j}$ is the landslide density of the class $i$ of parameter $j, f$ is the landslide density of the whole considered area, $A_{i j}^{*}$ is the landslide area in the class i of parameter $j, A_{i j}$ is the area of the class $i$ of parameter $j, A^{*}$ is the total landslide area, and $A$ is the total surface of the considered area. Therefore the higher the weight of a class, the greater is its influence in the instabilities. The method was first performed in the "training area" ( $\mathrm{T}$ in Fig. 1) that represents about $75 \%$ of the entire study area, and its robustness and prediction skill was then tested in an adjacent "test area". The numerical rating values for each class of the six causative factors are presented in Table 1.

The calculated weights indicate that, for the geology factor, the highest value is given by Plio-Pleistocene calcarenites. They outcrop over a very small part of the basin, forming cliffs just above the initiation points of some of the landslides. For this reason, the weight is high but it is likely that there is no direct influence of this lithology on instability. Relatively high weights also occur where large bodies of detritus or loose deposits cover the slopes. The Mandanici unit (phyllite) is by far the most favourable for landsliding compared to the other metamorphic units of the Peloritani Mountains.

For the geomechanical characteristics of the rock types, a clear trend is evident. Good rocks (according to the RMR classification) have no influence on landsliding, while poor ones favour instabilities.

For the geomorphological factor, the occurrence of large bodies of mobilized material and areas with concentrated flow erosion or strong erosional evidence have the highest influence. Rocky slopes and cliffs also have influence, because they can trigger shallow landslides through the fall of boulders.

Landslides occur when the slope angle is greater than $15^{\circ}$. The class with the highest incidence of landslides corresponds to high slope angles $\left(>45^{\circ}\right)$, while the frequency is lower for intermediate slope angles $\left(25^{\circ}-45^{\circ}\right)$.

Three classes of aspect factors influenced landsliding; in particular, south to southwest facing slopes were the most favourable. Areas located farther from the drainage network system (more than $150 \mathrm{~m}$ ) were the most unstable.

Calculated weights have been spatially summed together in order to map the landslide susceptibility index (LSI) for the entire study area.

The absolute value of LSI is meaningful only when it is classified into categories providing a qualitative estimate of susceptibility (Fell et al., 2008). For this reason the LSI has 


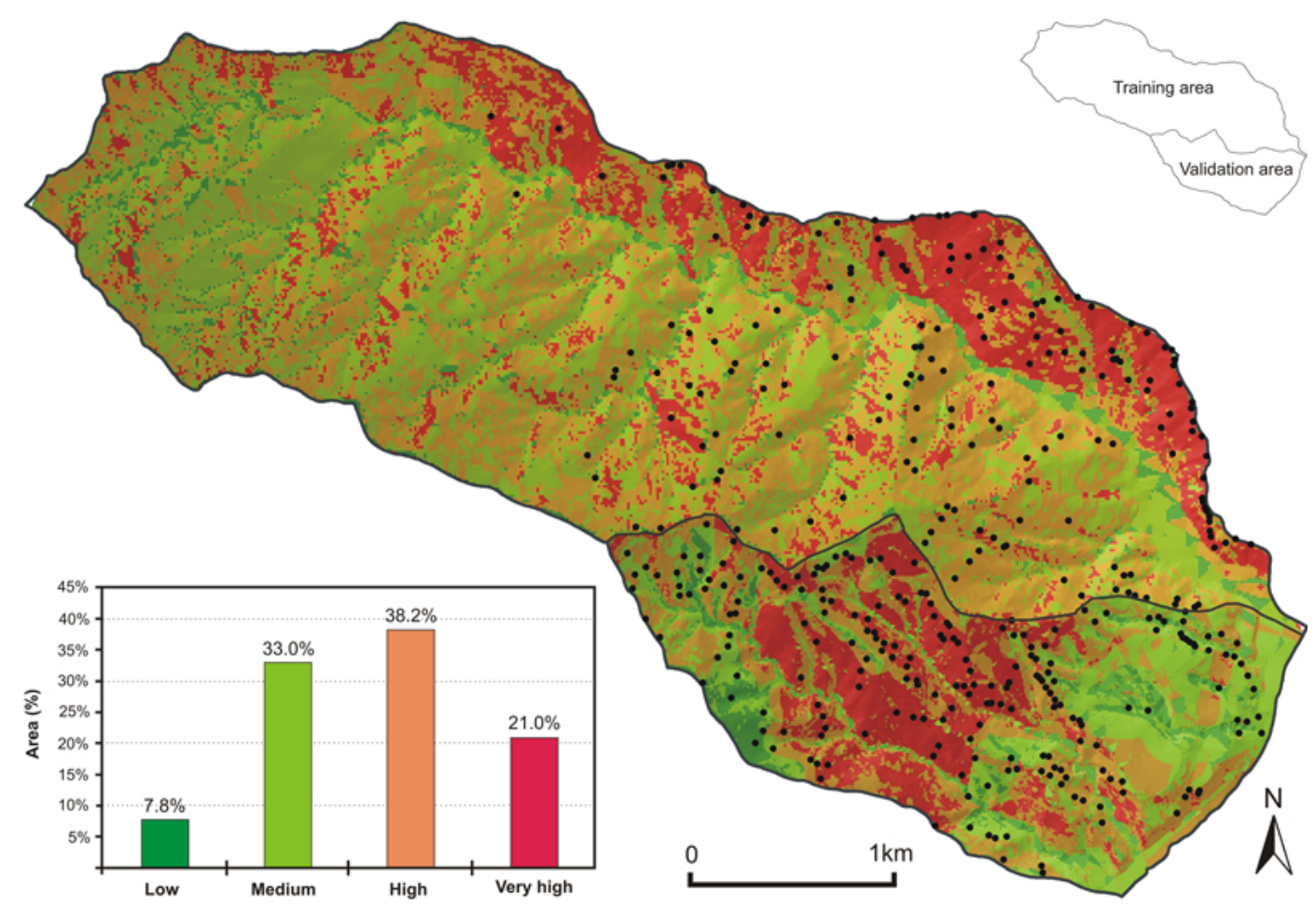

Fig. 5. Landslide susceptibility map subdivided in four landslide susceptibility classes: green, low susceptibility; light green, medium susceptibility; orange, high susceptibility; red, very high susceptibility. The bars show the percentage area within the different landslide susceptibility classes; black dots indicate the location of the landslides.

been classified into four different categories of susceptibility according to the most commonly used classification in the literature: low, medium, high and very high susceptibility.

Several subdivision procedures have been published that classify the LSI (expert-based, binary, equal interval, natural breaks, standard deviation, percentage of correspondence with landslides). In this study subdivision within the classes follows the criterion of natural breaks according to the Jenks' algorithm (Ruff and Czurda, 2008; Ruff and Rohn, 2008; Falaschi et al., 2009; Nandi and Shakoor, 2009; Piacentini et al., 2012) and was performed by analysing the frequency distribution of LSI. The natural breaks subdivision was preferred to other classification criteria, because the frequency distribution of the LSI shows obvious jumps. The final susceptibility map is shown in Fig. 5.

\subsection{Validation and prediction}

Validation of the susceptibility model is an essential procedure that assesses of how well it matches the distribution of landslides. Moreover, the use of independent landslide information is necessary to evaluate its sensitivity in forecasting future instabilities (Chung ad Fabbri, 2003; Guzzetti et al., 2006). There are different criteria with increasing grades of accuracy in the validation procedure. Guzzetti et al. (2006) also proposed a classification of the quality level of the susceptibility models and associated maps. Low quality models do not meet any tests of reliability, or validate the model with the same landslide information used to obtain the models themselves. High quality models estimate the error associated with the predicted susceptibility index value and, in addition, validate the model using independent landslide information that was not used to produce the model. The model presented here has been tested following this last criterion.

The effectiveness and the prediction skill of our model have been verified through a partition of the study area (Chung and Fabbri, 2003). We elaborated our model in the training area $(\mathrm{T})$, and the validation was performed in the remaining part $(\mathrm{V})$. We took into account the physiographical boundaries of the catchments, thus considering the watershed as boundaries of the training and validation areas (Fig. 5); $75 \%$ of the study area, containing 182 landslides, was used as the training set, while the remaining $25 \%$, containing 215 landslides, was used for model validation.

The validation area was excluded before assessment of the model; thus, the landslide susceptibility map was drawn up first and only subsequently combined with the landslide distribution data in the test area $(\mathrm{V})$ that is therefore independent of the model.

A quantitative assessment of the performance of the susceptibility model is provided by the success rate curve (Chung and Fabbri 2003; van Westen et al., 2003; Guzzetti et al., 2006; Poli and Sterlacchini, 2007; Blahut et al., 2010; 
Table 1. Calculated weights in the training areas for the classes of the six causative factors; ${ }^{*}$ arbitrarily assigned.

\begin{tabular}{|c|c|c|c|}
\hline $\begin{array}{l}\text { Instability } \\
\text { factor/Classes }\end{array}$ & $\begin{array}{r}\% \text { Area covered } \\
\text { by the class }\end{array}$ & $\begin{array}{r}\text { Landslide } \\
\text { density }(\%)\end{array}$ & Weight \\
\hline \multicolumn{4}{|l|}{ Lithology } \\
\hline Slope deposit & $1.33 \%$ & $2.7 \%$ & 0.69 \\
\hline Present-day alluvial deposits & $2.06 \%$ & $0.0 \%$ & 0.00 \\
\hline Recent alluvial deposits & $1.24 \%$ & $0.0 \%$ & 0.00 \\
\hline Calcarenites & $0.09 \%$ & $2.2 \%$ & $* 1.00$ \\
\hline Aspromonte unit (gneiss) & $48.35 \%$ & $41.9 \%$ & -0.14 \\
\hline Mela unit (mica schist) & $21.82 \%$ & $10.2 \%$ & -0.76 \\
\hline Mandanici unit (phyllite) & $20.61 \%$ & $42.9 \%$ & 0.73 \\
\hline Marble & $4.49 \%$ & $0.0 \%$ & 0.00 \\
\hline \multicolumn{4}{|l|}{ Geomechanical classification } \\
\hline Very good & $3.62 \%$ & $0.0 \%$ & 0.00 \\
\hline Good & $11.57 \%$ & $0.4 \%$ & -3.49 \\
\hline Fair & $49.41 \%$ & $67.8 \%$ & 0.32 \\
\hline Poor & $30.67 \%$ & $26.9 \%$ & -0.13 \\
\hline Very poor & $4.73 \%$ & $4.9 \%$ & 0.04 \\
\hline \multicolumn{4}{|l|}{ Geomorphology } \\
\hline Rock slopes and cliffs & $8.70 \%$ & $13.9 \%$ & 0.47 \\
\hline Colluvial slopes & $78.17 \%$ & $78.1 \%$ & 0.00 \\
\hline Concentrated flow erosion & $5.09 \%$ & $2.5 \%$ & -0.72 \\
\hline Areas with diffuse erosion & $0.33 \%$ & $0.3 \%$ & -0.07 \\
\hline Alluvial & $2.06 \%$ & $0.0 \%$ & 0.00 \\
\hline Quaternary sediments & $1.24 \%$ & $0.0 \%$ & 0.00 \\
\hline Terraced elements & $3.20 \%$ & $2.6 \%$ & -0.22 \\
\hline Detritus & $1.22 \%$ & $2.6 \%$ & 0.77 \\
\hline \multicolumn{4}{|l|}{ Slope angle $\left(^{\circ}\right)$} \\
\hline$<5$ & $5.11 \%$ & $2.5 \%$ & -0.72 \\
\hline $5-15$ & $4.07 \%$ & $0.9 \%$ & -1.55 \\
\hline $15-25$ & $19.03 \%$ & $14.9 \%$ & -0.24 \\
\hline $25-35$ & $38.65 \%$ & $40.2 \%$ & 0.04 \\
\hline $35-45$ & $25.50 \%$ & $30.5 \%$ & 0.18 \\
\hline$>45$ & $7.65 \%$ & $11.0 \%$ & 0.37 \\
\hline \multicolumn{4}{|l|}{ Aspect } \\
\hline Flat & $5.03 \%$ & $2.5 \%$ & -0.70 \\
\hline North & $8.67 \%$ & $6.4 \%$ & -0.30 \\
\hline Northeast & $18.68 \%$ & $18.6 \%$ & -0.01 \\
\hline East & $18.28 \%$ & $12.3 \%$ & -0.39 \\
\hline Southeast & $13.11 \%$ & $9.7 \%$ & -0.30 \\
\hline South & $11.64 \%$ & $17.2 \%$ & 0.39 \\
\hline Southwest & $5.93 \%$ & $11.4 \%$ & 0.65 \\
\hline West & $2.16 \%$ & $4.2 \%$ & 0.66 \\
\hline Northwest & $7.40 \%$ & $4.2 \%$ & -0.56 \\
\hline North & $9.09 \%$ & $13.5 \%$ & 0.39 \\
\hline \multicolumn{4}{|l|}{ Distance to stream } \\
\hline$<30$ & $24.01 \%$ & $5.0 \%$ & -1.58 \\
\hline $30-150$ & $60.05 \%$ & $69.0 \%$ & 0.14 \\
\hline$>150$ & $15.94 \%$ & $26.0 \%$ & 0.49 \\
\hline
\end{tabular}

Piacentini et al., 2012). This is drawn by plotting on the $\mathrm{x}$-axis the cumulative percentage of the study area within each class of susceptibility and on the $y$-axis the cumulative percentage of landslides in each susceptibility class, ranked from the most to the least susceptible. The shape of the curve gives information about the degree of success of the model - the larger the area under the curve, the better is the performance in fitting the landslide distribution. For the susceptibility model in the study area, the curve rapidly departed

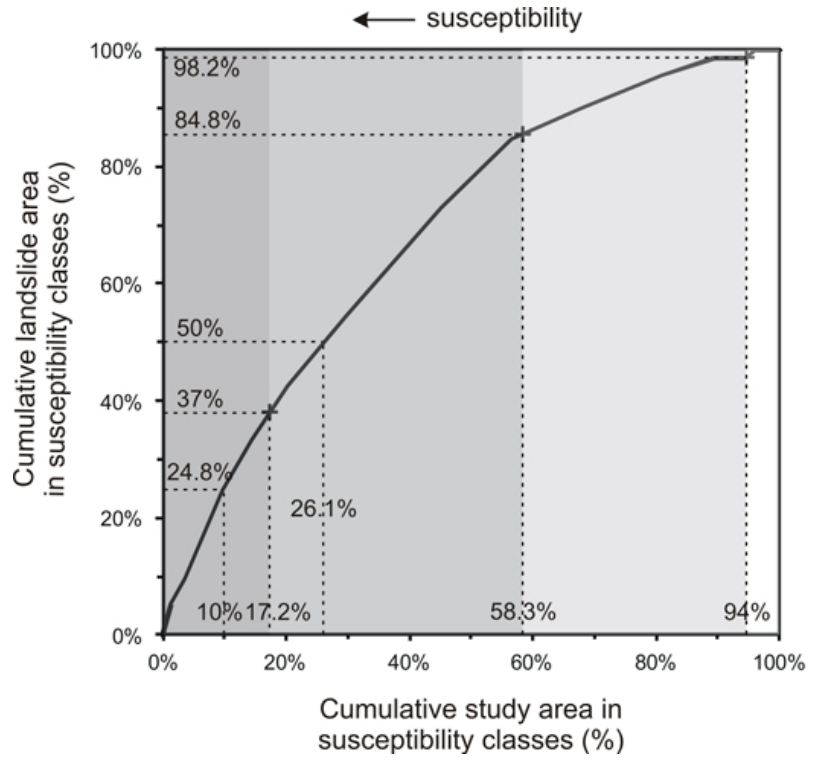

Fig. 6. Analysis of the fitting degree of landslide susceptibility model.

from the $\mathrm{x}$-axis and then approximated this axis in its final part, and the area under the curve (ACU) is 0.70, indicating a good success rate (Fig. 6). In detail half of the landslides $(50 \%)$ are found in the $26.1 \%$ most susceptible zone, and approximately a quarter $(24.8 \%$ ) of the landslides fall within the most susceptible $10 \%$ of the area. The area evaluated and mapped as very highly or highly susceptible covers $84.4 \%$ of the total mapped landslides, and only $1.8 \%$ of the landslides are mapped in the lower susceptibility class.

In the validation area we used independent landslide information in order to test the ability of the model to predict the locations of landslides. We plotted the cumulative percentage of landslides as a function of the spatial probability of occurrence (Fig. 7). Very few landslides (5.9\%) were within the lower class of susceptibility, while $70.9 \%$ of landslides were correctly classified by the model as they occur in regions classified as being of high or very high susceptiblity.

\section{Tectonic implications}

The bivariate technique allowed us to perform and successively validate a susceptibility model for shallow landslides, proving the relevance of each geo-environmental factor in landsliding and the relative weight of each class. In this way we have been able to identify combinations of main factors leading to instability. These combinations generally consist of poor or very poor rock types, especially paragneiss and phyllite, steep $\left(35^{\circ}-45^{\circ}\right)$ colluvial slopes or slopes covered by loose deposits, and at distance from the drainage network.

The occurrence of such combinations can be considered in framework of the geological heritage of the region of the Peloritani Mts. 


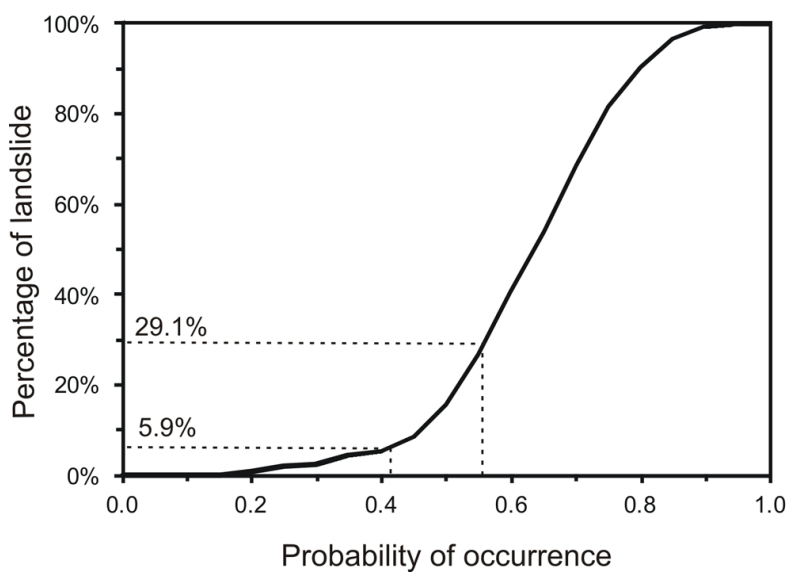

Fig. 7. Analysis of the landslide susceptibility map in the validation area $(\mathrm{V})$ in relation to the distribution of the landslides.

Vertical tectonic deformation, acting intensely especially during the last 5000-6000 yr, contributed to the topographic rejuvenation of the relief by inducing erosional processes (Cyr et al., 2010) and allowing the release of lithostatic load causing a shallow and dense net of discontinuities in the rock masses. The denudation process is also favoured by geological conditions of highly deformed and weatheringprone metamorphic rocks (Morgagni et al., 1993; Le Pera and Sorriso-Valvo, 2000; Snyder et al., 2003; Calcaterra and Parise, 2005; Marques et al., 2010; Goswami et al., 2011). Lithostatic release and erosion mutually enhance their effects by favouring degradation of the rock masses (Riebe et al., 2001; Hren et al., 2007) and consequently the acceleration of slope processes where the normal evolution of the landscape involves a slower cyclical accumulation and mobilization of loose superficial material (Dietrich et al., 1982; Burbank, 2002).

In a mountain range bounded by active normal faults, relief responds very quickly to changes in the base level (Densmore et al., 1998; Goldsworthy and Jackson, 2000); even in a period of a century or less, river systems are able to adjust to the deformation (Keller and Pinter, 1996). Footwall uplift produces short, steep catchments in which the effects of tectonics are reflected both by the state of activity of the streams and the arrangement of the whole fluvial network.

In the study area the activity of the Taormina fault controls coastline shape over a whole sector of the Peloritani mountain range. The long-term activity of the fault induced the formation of a consequent drainage network represented by the main streams of the catchments. In an attempt to reach equilibrium with the tectonic activity, the main stream incisions undergo intense linear erosion and the slopes become steeper, while the erosional processes become weaker moving upwards to the secondary network (Catalano and De Guidi, 2003; Goswami et al., 2012). This allows indirect coupling of factors such as aspect or distance from the network with recent tectonic activity.

Slope aspect involved in instabilities is not only connected with hydrological or weathering processes, but also with the morphological evolution of the relief. In fact, the highest weights in landslide occurrence for $\mathrm{S}-\mathrm{SW}$ and $\mathrm{N}$-facing slopes (Table 1 ) are usually linked to the $\sim$ WNW-ESE directed consequent drainage (Fig. 8). Similarly, because the slopes of the consequent valleys are wider (transversely) and longer (longitudinally), the number of instabilities increases with the distance from the streams. These slopes are undisturbed by the continuous erosion along stream segments, and a greater amount of sediment can accumulate. In contrast, for areas that are very close to stream segments, the formation of colluvium is retarded, and a sufficient thickness of colluvial material necessary for the occurrence of the types of instabilities considered here does not accumulate.

The relationship between recent tectonic activity and landslide distribution has also been highlighted by Goswami et al. (2011). These authors obtained the same result through frequency-area landslide statistics, showing that instabilities are mainly located where the effects, direct or indirect, of fault activity are the greatest.

\section{Concluding remarks}

A landslide susceptibility analysis for a representative area of the Peloritani mountain range has been carried out. The results of the validation and prediction prove the effectiveness of the model; in fact, within the performance scheme of Guzzetti et al. (1999), the model shows an acceptable percentage of correctly classified landslides. Consequently it is possible to extend the model from a relatively small area to a larger region with similar geological and geomorphological conditions.

The bivariate technique method separates each considered factor not providing their relative weights. For this reason the final map is a simple combination of factors which, although recognized as the most important ones, may not have equal incidence. For this reason, our results could be further improved by the application of more sophisticated methods for the analysis of susceptibility (i.e. multivariate techniques) that allow estimation of the relative influence of single causative factors.

Nevertheless, the experience gained during field surveys allowed us to select the most relevant factors, enhancing the reliability of the results. Fieldwork is of fundamental importance for a reliable mapping of the factors contributing to landslides, such as lithology, lithotechnical parameters and colluvium coverage. In addition, we suggest that the influence of active tectonics, and its spatial variation over the entire Peloritani region, should be taken into account as causative factors in future small-scale susceptibility assessments. 


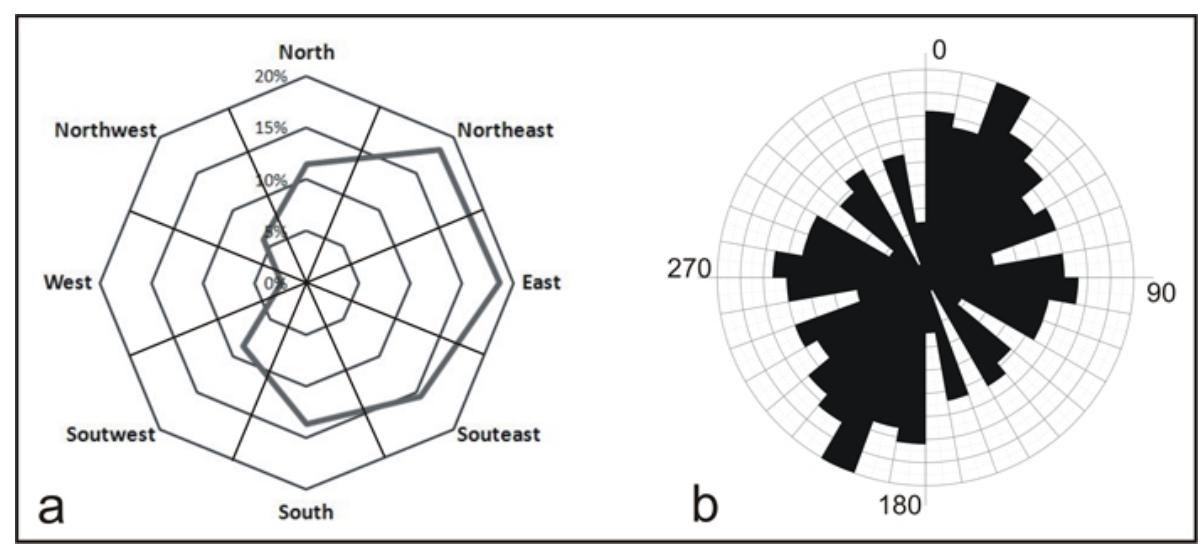

Fig. 8. (a) frequency distribution of the slope aspect within the whole study area: the highest value is for east-dipping slope; relative maxima are also for northeast- and south-facing slopes. (b) frequency distribution of the direction of the stream segments for the four considered catchments; note the peaks at SSW-NNE and at WNW-ESE directions.

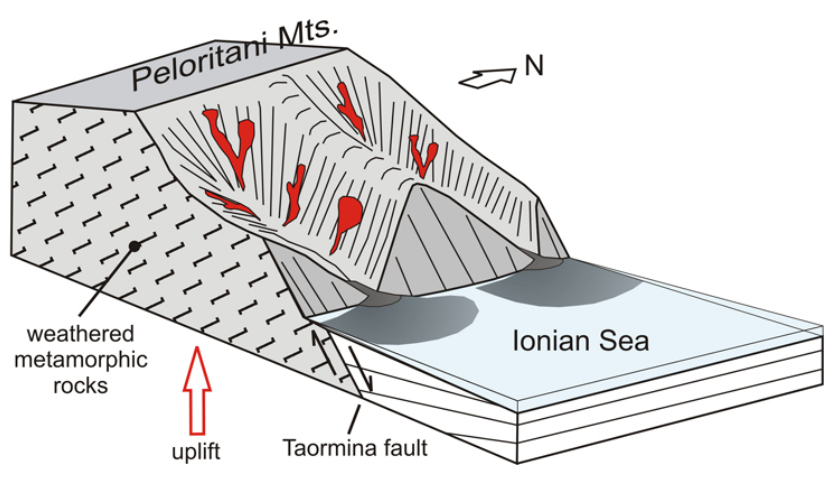

Fig. 9. Sketch summarizing the morphological, geological and tectonic features of the Peloritani Mts. Modified from Goldsworthy and Jackson (2000).

The assessment of landslide susceptibility allowed us to speculate about the effect of geological dynamics on the geomorphological evolution of relief. Our investigations focused on four representative basins, and we were able to infer some direct relationships between the general setting, derived from the active endogenic dynamics, and the superficial phenomena of relief evolution for this sector.

Erosion is favoured by geological conditions: metamorphic rocks in particular are very prone to chemical weathering. Tectonic uplift coupled with strong erosion allows the release of the lithostatic load originating as a shallow and dense net of discontinuities in the rock mass. These processes act together by favouring the weathering and consequently the formation of loose and heterogeneous material that covers most of the slopes and becomes cyclically unstable under critical conditions (e.g. extreme rainfall, earthquakes) (Fig. 9).

It was not possible to calculate the recurrence interval for the triggering rainfall events as this is much longer than the available historical records (Vecchio, 2011). Therefore, in a temporal perspective, these events are very rare and their influence on relief processes is not decisive.

The role played by fluvial bedrock incision, tectonic uplift and landslides in the evolution of relief is not universal, but rather changes from one mountain range to the other as well as with time (Korup et al., 2010). In different sectors of the Calabrian arc, several studies (Goswami et al., 2011, 2012; Santangelo et al., 2011) have recognized the direct influence of Quaternary tectonics (uplift and faulting) on mass movements and its greater relevance with respect the lithostructural and morphoclimatic factors.

In conclusion, considering the almost homogeneous geological and environmental conditions in the eastern sector of the Peloritani Mts., the landslide susceptibility model developed here could be extended without any particular integration, to the entire ridge area. Of course our model contains some limitations for this extension (limited catalogue extent, single landslide type analysed), and also other landslide susceptibility assessment methods could be tested. The spatial distribution of landslide susceptibilities highlights how large portions of the study area (about $20 \%$ ), and likely of the whole Peloritani Mts. area, are characterized by very high susceptibility. Therefore triggering events similar to that of October 1st 2009 will certainly occur again in the future. Consequently the susceptibility analysis is important not only for an understanding of the geological dynamics, but also because it represents a fundamental step in landslide hazard mitigation in the Peloritani Mts.

Acknowledgements. We are grateful to Thomas Dewez (BRGM), Rajasmita Goswami (University of Manchester) and two anonymous reviewers for their constructive criticism on the originally submitted manuscript. We also thank Guido De Guidi (University of Catania) and Paul Taylor (Natural History Museum, London) for the English review. This work was supported by grants from the University of Catania (responsible C. Monaco and G. De Guidi). 
Edited by: F. Guzzetti

Reviewed by: T. Dewez, R. Goswami, and two anonymous referees

\section{References}

Agliardi, F., Zanchi, A., and Crosta, G. B.: Tectonic vs. gravitational morphostructures in the central Eastern Alps (Italy): Constraints on the recent evolution of the mountain range, Tectonophys., 474, 250-270, 2009.

Agnesi, V., Rasà, R., Puglisi, C., Gioè, C., Privitera, B., Cappadonia, C., Conoscenti, C., Pino, P., and Rotigliano, E.: La franosità diffusa dell'1 Ottobre 2009 nel territorio ionico-peloritano della Provincia di Messina: stato delle indagini e prime considerazioni sulle dinamiche geomorfiche attivate, Geologi di Sicilia, 23-30, 2009.

Amodio-Morelli, L., Bonardi, G., Colonna, V., Dietrich, D., Giunta, G., Ippolito, F., Liguori, V., Lorenzoni, S., Paglionico, A., Perrone, V., Piccarreta, G., Russo, M., Scandone, P., ZanettinLorenzoni, E., and Zuppetta, A.: L'Arco Calabro-peloritano nell'orogene appenninico-maghrebide, Mem. Soc. Geol. It., 17, 1-60, 1976.

Antonioli, F., Kershaw, S., Rust, D., and Verrubbi, V.: Holocene sealevel change in Sicily and its implications for tectonic models: new data from the Taormina area, northeast Sicily, Mar. Geol., 196, 53-71, 2003.

Antonioli, F., Kershaw, S., Renda, P., Rust, D., Belluomini, G., Cerasoli, M., Radtke, U., and Silenzi, S.: Elevation of the last interglacial highstand in Sicily (Italy): A benchmark of coastal tectonics, Q. Int., 145-146, 3-18, 2006.

Antonioli, F., Ferranti, L., Fontana, A., Amorosi, A., Bondesan, A., Braitenberg, C., Dutton, A., Fontolan, G., Furlani, S., Lambeck, K., Mastronuzzi, G., Monaco, C., Spada, G., and Stocchi, P.: Holocene relative sea-level changes and vertical movements along the Italian and Istrian coastlines, Q. Int., 206, 102-133, 2009.

APAT, Servizio Geologico d'Italia, Dipartimento Difesa del Suolo: Note illustrative della Carta Geologica d'Italia alla scala 1:50.000, Foglio 601 Messina. Reggio di Calabria, S.EL.CA, Firenze, 2008.

APAT, Servizio Geologico d'Italia, Dipartimento Difesa del Suolo: Note illustrative della Carta Geologica d'Italia alla scala 1:50.000, Foglio 613 Taormina, S.EL.CA, Firenze, 2010.

Basile, G.: Evento del 1 Ottobre 2009, Carta dei dissesti, Dipartimento Regionale della Protezione Civile, Sicilia, 2010.

Bieniawski, Z.T.: The geomechanics classification in rock engineering applications. Proceedings of 4th International Congress on Rock Mechanics, 2-8 September 1979. Montreux, Switzerland, 1979.

Blahut, J., van Westen, C. J., and Sterlacchini, S.: Analysis of landslide inventories for accurate prediction of debris-flow source areas, Geomorphology, 119, 36-51, 2010.

Bonardi, G., Cello, G., Perrone, V., Tortorici, L., Turco, E., and Zuppetta, A.: The evolution of the northern sector of the CalabriaPeloritani arc in a semiquantitative palynspastic restoration, Boll. Soc. Geol. It., 101, 259-284, 1982.

Bonardi, G., de Capoa, P., Di Staso, A., Martin-Martin, M., MartinRojas, I., Perrone, V., Tent-Manclus, J.E.: New constraints to the geodynamic evolution of the southern sector of the CalabriaPeloritani Arc (Italy), C. R. Geosci., 334, 423-430, 1982.

Borrelli, L., Greco, R., and Gullà, G.: Weathering grade of rock masses as a predisposing factor to slope instabilities: Reconnaissance and control procedures, Geomorphology, 84, 158-175, 2007.

Brenning, A.: Spatial prediction models for landslide hazards: review, comparison and evaluation, Nat. Hazards Earth Syst. Sci., 5, 853-862, doi:10.5194/nhess-5-853-2005, 2005.

Burbank, D. W.: Rates of erosion and their implications for exhumation, Mineral. Mag., 66/1, 25-52, 2002.

Burbank, D. W. and Pinter, N.: Landscape evolution: the interactions of tectonics and surface processes, Basin Res., 11, 1-6, 1999.

Calcaterra, D. and Parise, M.: Landslide types and their relationships with weathering in a Calabrian basin, southern Italy, Bull. Eng. Geol. Environ., 64, 193-207, 2005.

Carrara, A., Cardinali, M., Detti, R., Guzzetti, F., Pasqui, V., and Reichenbach, P.: GIS techinques and statistical models in evalueting landslide hazard, Earth Process. Surf. Landforms, 16, 427-445, 1991.

Carrara, A., Guzetti, F., Cardinali, M., and Reichenbach, P.: Use of GIS Technology in the Prediction and Monitoring of Landslide Hazard, Nat. Hazards, 20, 117-135, 1999.

Cascini, L.: Applicability of landslide susceptibility and hazard zoning at different scales, Eng. Geol., 102, 164-177, 2008.

Catalano, S. and De Guidi, G.: Late Quaternary uplift of northeastern Sicily: relation with the active normal faulting deformation, J. Geodynam., 36, 445-467, 2003.

Catalano, S., De Guidi, G., Monaco, C., Tortorici, G., and Tortorici, L.: Long-term behaviour of the late Quaternary normal faults in the Straits of Messina area (Calabrian arc): structural and morphological constraints, Q. Int., 101/102, 81-91, 2003.

Catalano, S., De Guidi, G., Monaco, C., Tortorici, G., and Tortorici, L.: Active faulting and seismicity along the Siculo-Calabrian Rift Zone (southern Italy), Tectonophys., 453, 177-192, 2008.

Cevik, E. and Topal, T.: GIS-based landslide susceptibility mapping for a problematic segment of the natural gas pipeline, Hendek (Turkey), Environ. Geol., 44, 949-962, 2003.

Chung, C. F. and Fabbri, A. G.: Validation of Spatial Prediction Models for Landslide Hazard Mapping, Nat. Hazards, 30, 451472, 2003.

Claessens, L., Schoorl, J. M., and Veldkamp, A.: Modelling the location of shallow landslides and their effects on landscape dynamics in large watersheds: An application for Northern New Zealand, Geomorphology, 87, 16-27, 2007.

Cyr, A. J., Granger, D. E., Olivetti, V., and Molin, P.: Quantifying rock uplift rates using channel steepness and cosmogenic nuclide-determined erosion rates: Examples from northern and southern Italy, Lithosphere, 2/3, 188-198, 2010.

D'Agostino, N. and Selvaggi, G.: Crustal motion along the EurasiaNubia boundary in the Calabrian Arc and Sicily and active extension in the Messina Straits from GPS measurements, J. Geophys. Res., 109, B11402, doi:10.1029/2004JB002998, 2004.

Dai, F. C. and Lee, F.: A Spatiotemporal probabilistic modeling of storm-induced shallow landsliding using aerial photograps and logistic regression, Earth Surf. Proc. Land., 28, 527-545, 2003.

Deb, S. K. and El-Kadi, A. I.: Susceptibility assessment of shallow landslides on Oahu, Hawaii, under extreme-rainfall events, Geo- 
morphology, 108, 129-233, 2009.

De Gregorio, S., Rotolo, S. G., and Villa, I. M.: Geochronology of the medium to high-grade metamorphic units of the Peloritani Mts., Sicily, Int. J. Earth Sci., 92, 852-872, 2003.

De Guidi, G., Catalano, S., Monaco, C., and Tortorici, L.: Morphological evidence of Holocene coseismic deformation in the Taormina region (NE Sicily), J. Geodynam., 36, 193-211, 2003.

Deere, D. U. and Miller, R. P.: Engineering classification and index properties for intact rock, Air Force Weapons Laboratory Technical Report, AFWL-TR-65-116, 277 pp. 1966.

Densmore, A. L., Ellis, M. A., and Anderson, R. S.: Landsliding and the evolution of normal-fault-bounded mountains, J. Geophy. Res., 103, 15203-15219, 1998.

Dietrich, W. E., Dunne, T., Humphrey, N. F., and Reid, L. M.: Construction of sediment budgets for drainage basins, Sediment Budgets and routing in forested drainage basins, Proceedings of the Symposium; 31 May - 1 June 1982; Corvallis, Oregon. Gen. Tech. Rep. PNW-141. Portland, Oregon: Pacific Northwest Forest and Range Experiment Station, Forest Service, U.S. Department of Agriculture, 5-23, 1982.

Falaschi, F., Giacomelli, F., Federici, P. R., Puccinelli, A., D’Amato Avanzi, G., Pochini, A., and Ribolini, A.: Logistic regression versus artificial neural networks: landslide susceptibility evaluation in a sample area of the Serchio River valley, Italy, Nat. Hazards, 50, 551-569, 2009.

Falconi, L., Campolo, D., Leoni, G., Lumaca, S., and Puglisi, C.: Geomorphology hazard assessment of Giampilieri and Briga river basins after the rainfall event on the October 1, 2009 (Sicily, Italy), The Second World Landslide Forum, "Putting science into practice". Global Promotion Committee of the International Programme on Landslides (IPL), Rome, Italy, 2011.

Federici, P. R., Puccinelli, A., Cantarelli, E., Casarosa, N., D’Amato Avanzi, G., Falaschi, F., Giannecchini, R., Pochini, A., Ribolini, A., Bottai, M., Salvati, N., and Testi, C.: Multidisciplinary investigations in evaluating landslide susceptibility. An example in the Serchio River valley (Italy), Q. Int., 171-172, 52-63, 2007.

Fell, R., Corominas, J., Bonnard, C., Cascini, L., Leroi, E., and Savage, W. Z.: On behalf of the JTC-1 Joint Technical Committee on Landslides and Engineered Slopes: Guidelines for landslide susceptibility, hazard and risk zoning for land use planning, Eng. Geol., 102, 85-98, 2008.

Festa, V., Messina, A., Paglionico, A., Piccarreta, G., and Rottura, A.: Pre-Triassic history recorded in the Calabria-Peloritani segmento $f$ the Alpine chain, southern Italy. An overview, Per. Mineral., 73, 57-71, 2004.

Giunta, G. and Nigro, F.: Tectono-sedimentary constraints to the Oligocene-to-Miocene evolution of the Peloritani thrust belt (NE Sicily), Tectonophys, 315, 287-299, 1999.

Glade, T.: Establishing the frequency and magnitude of landslidetriggering rainstorm events in New Zealand, Environ. Geol., 35, 160-174, 1998.

Godt, J. W., Baum R. L., Savage, W. Z., Salciarini, D., Schultz, W. H., and Harp, E. L.: Transient deterministic shallow landslide modeling: Requirements for susceptibility and hazard assessments in a GIS framework, Eng. Geol,. 102, 214-236, 2008.

Goldsworthy, M. and Jackson, J.: Active normal fault evolution in Greece revealed by geomorphology and drainage patterns, J. Geol. Soc. London, 157, 967-981, 2000.
Goswami, R., Mitchell, N. C., and Brocklehurst, S. H.: Distribution and causes of landslides in eastern Peloritani of NE Sicily and western Aspromonte of SW Calabria, Italy, Geomorphology, 132, 111-122, 2011.

Goswami, R., Brocklehurst, S. H., and Mitchell, N. C.: Erosion of a tectonically uplifting coastal landscape, NE Sicily, Italy, Geomorphology, 171-172, 114-126, 2012.

Grande, A., Di Vincenzo, G., Prosser, G., and Caggianelli, A.: Direct evidence of Middle Oligocene extension in the CalabriaPeloritani terrane from co-seismic faulting: the pseudotachylytebearing shear zones of Palmi (southern Calabria, Italy), T. Nov., 21, 293-303, 2009.

Greco, R. and Sorriso-Valvo, M.: Relationships between joint apparent separation, Schmidt hammer rebound value, and distance to faults, in rocky outcrops, Calabria, Southern Italy, Eng. Geol., 78, 309-320, 2005.

Guarnieri, P. and Pirrotta, C.: The response of drainage basins to the late Quaternary tectonics in the Sicilian side of the Messina Strait (NE Sicily), Geomorphology, 95, 260-273, 2008.

Gullà, G., Antronico, L., Iaquinta, P., and Terranova, O.: Susceptibility and triggering scenarios at a regional scale for shallow landslides, Geomorphology, 99, 39-58, 2008.

Günther, A. and Thiel, C.: Combined rock slope stability and shallow landslide susceptibility assessment of the Jasmund cliff area (Rügen Island, Germany), Nat. Hazards Earth Syst. Sci., 9, 687698, doi:10.5194/nhess-9-687-2009, 2009.

Guzzetti, F., Carrara, A., Cardinali, M., and Reichenbach, P.: Landslide hazard evaluation: a review of current techniques and their application in a multi-scale study, Central Italy, Geomorphology, 31, 181-216, 1999.

Guzzetti, F., Reichenbach, P., Cardinali, M., Galli, M., Ardizzone, F.: Probabilistic landslide hazard assessment at the basin scale, Geomorphology, 72, 272-299, 2005.

Guzzetti, F., Reichenbach, P., Ardizzone, F., Cardinali, M., and Galli, M.: Estimating the quality of landslide susceptibility models, Geomorphology, 81, 166-184, 2006.

Harp, H. L., Reid, M. E., McKenna, J. P., and Michael, J. A.: Mapping of hazard from rainfall-triggered landslides in developing countries: Examples from Honduras and Micronesia, Eng. Geol., 104, 295-311, 2009.

Hengl, T.: Finding the right pixel size, Comput. Geosci., 32, 1283 1298, 2006.

Heymes, T., Monié, P., Arnaud, N., Pêcher, A., Bouillin, J. P., and Compagnoni, R.: Alpine tectonics in the Calabrian-Peloritan belt (southern Italy): New 40Ar/39Ar data in the Aspromonte Massif area, Lithos 114, 461-472, 2010.

Hren, M. T, Hilley, G. E., and Chamberlain, C. P.: The relationship between tectonic uplift and chemical weathering rates in the Washington Cascades: field measurements and model predictions, Am. J. Sci., 307, 1041-1063, 2007.

ISRM, International Society on Rock Mechanics: Basic geotechnical description of rock masses, Int. J. Rock Mech. Min. Sci. Geomech. Ab., 18, 85-110, 1981.

Keller, E. A. and Pinter, N.: Active Tectonics: Earthquakes, Uplift, and Landscape, Prentice Hall, Upper Saddle River, New Jersey, 338 pp., 1996.

Korup, O., Clague, J. J., Hermanns, R. L., Hewitt, K., Strom, A. L., and Weidinger, J. T.: Giant landslides, topography, and erosion, Earth Pl. Sci. Lett., 261, 578-589, 2007. 
Korup, O., Densmore, A. L., and Schlunegger, G.: The role of landslides in mountain range evolution, Geomorphology, 102, 77-90, 2010.

Lacerda, W.: Landslide initiation in saprolite and colluvium in southern Brazil: Field and laboratory observations, Geomorphology, 87, 104-119, 2007.

Lambeck, K., Antonioli, F., Purcell, A., and Silenzi, S.: Sea-level change along the Italian coast for the past $10000 \mathrm{yr}$, Quaternary Sci. Rev., 23 , 1567-1598, 2004.

Le Pera, E. and Sorriso-Valvo, M.: Weathering and morphogenesis in a Mediterranean climate, Calabria, Italy, Geomorphology, 34, 251-270, 2000.

Marques, E. A. G., Barroso, E. V., Menez Filho, A. P., and Vargas, Jr. E. A.: Weathering zones on metamorphic rocks from Rio de Janeiro-Physical, mineralogical and geomechanical characterization, Eng. Geol., 111, 1-18, 2010.

Maugeri, M. and Motta, E.: Effects of Heavy Rainfalls on Slope Behaviour: The October 1, 2009 Disaster of Messina (Italy), Geotechnics/Earthquake Geotechnics towards Global Sustainability, Kyoto, Japan, 12-14 January, 2010.

Monaco, C. and Tortorici, L.: Active faulting in the Calabrian arc and eastern Sicily, J. Geodynam., 29, 407-424, 2000.

Monaco, C., Tortorici, L., Nicolich, R., Cernobori, L., and Costa, M.: From collisional to rifted basins: an example from the southern Calabrian arc (Italy), Tectonophys., 266, 233-249, 1996.

Monaco, C., Tapponier, P., Tortorici, L., and Gyllot, P. Y.: Late Quaternary slip rates on the Acireale-Piedimonte normal faults and tectonic origin of Mt. Etna (Sicily), Earth Planet. Sci. Lett., 147, 125-139, 1997.

Montenat, C., Barrier, P., and d'Estevou, P.: Some aspects of the recent tectonics in the Strait of Messina, Italy, Tectonophys., 194, 203-215, 1991.

Montgomery, D. R. and Brandon, M., T.: Topographic controls on erosion rates in tectonically active mountain ranges, Earth Pl. Sci. Lett., 201, 481-489, 2002.

Morgagni, A., Marsigli, M., and Todini, E.: Assessment of soil erosion in a number of small ephemeral streams in Calabria and Sicily, Proc. Workshop on Soil Erosion in Semi-arid Mediterranean Areas, European Society for Soil Conservation, Centro Studi per l'Economia applicata all'Ingegneria, 137-148, 1993.

Nandi, A. and Shakoor, A.: A GIS-based landslide susceptibility evaluation using bivariate and multivariate statistical analyses, Eng. Geol., 110, 11-20, 2009.

Pellegrino, A. and Prestininzi, A.: Impact of weathering on the geomechanical properties of rocks along thermal-metamorphic contact belts and morpho-evolutionary processes: The deepseated gravitational slope deformations of Mt. GranieriSalincriti (Calabria-Italy), Geomorphology, 87, 176-195, 2007.

Piacentini, D., Troiani, F., Soldati, M., Notarnicola, C., Savelli, D., Schneiderbauer, S., and Strada, C.: Statistical analysis for assessing shallow-landslide susceptibility in South Tyrol (south-eastern Alps, Italy), Geomorphology, 151/152, 196-206, 2012.

Poli, S. and Sterlacchini, S.: Landslide Representation Strategies in Susceptibility Studies using Weights-of-Evidence Modeling Technique, Nat. Resources Res., 16, 121-134, 2007.

Riebe, C. S., Kirchner, J. W., Granger, D. E., and Finkel, R. C.: Strong tectonic and weak climatic control of long-term chemical weathering rates, Geology, 29/ 6, 511-514, 2001.
Ruff, M. and Czurda, K.: Landslide susceptibility analysis with a heuristic approach in the Eastern Alps (Vorarlberg, Austria), Geomorphology, 94, 314-324, 2008.

Ruff, M. and Rohn, J.: Susceptibility analysis for slides and rockfall: an example from the Northern Calcareous Alps (Vorarlberg, Austria), Environ. Geol., 55, 441-452, 2008.

Rust, D. and Kershaw, S.: Holocene tectonic uplift patterns in northeastern Sicily: evidence from marine notches in coastal outcrops, Mar. Geol., 167, 105-126, 2000.

Sabato, L. and Tropeano, M.: Fiumara: a kind of high hazard river, Phys. Chem. Earth., 29, 717-715, 2004.

Salciarini, D., Godt, J. W., Savage, W. Z., Conversini, P., Baum, R. L., and Michael, J. A.: Modeling regional initiation of rainfallinduced shallow landslides in the eastern Umbria Region of central Italy, Landslides, 3, 181-194, 2006.

Salciarini, D., Godt, J. W., Savage, W. Z., Baum, R. L., and Conversini, P.: Modeling landslide recurrence in Seattle, Washington, USA, Eng. Geol., 102, 227-237, 2008.

Santangelo, M., Gioia, D., Fiorucci, F., Cardinali, M., Guzzetti, F., and Schiattarelli, M.: Relationships between mass movements and tectonic uplift in the upper Sinni River valley, Calabria-Lucania border, Southern Italy, Geophys. Res. Abstr. 13, EGU2011-11674, EGU General Assembly 2011, Vienna, Austria, 2011.

Singh, L. P., van Westen, C. J., Champati Ray, P. K., and Pasquall, P.: Accuracy assessment of InSAR derived inputmaps for landslide susceptibility analysis: a case study from the Swiss Alps, Landslides, 2, 221-228, 2005.

Scudero, S. and De Guidi, G.: Landslide processes and susceptibility mapping in NE Sicily, Italy. The Second World Landslide Forum, "Putting science into practice", Global Promotion Committee of the International Programme on Landslides (IPL), Rome, Italy, 2011.

Snyder, N. P., Whipple, K. X., Tucker, G. E., and Merritts, D. J.: Interaction between onshore bedrock-channel incision and nearshore wave-base erosion forced by eustasy and tectonics, Basin Res., 14, 105-127, 2002.

Snyder, N. P., Whipple, K. X., Tucker, G. E., and Merritts, D. J.: Channel response to tectonic forcing: field analysis of stream morphology and hydrology in the Mendocino triple junction region, northern California, Geomorphology, 53, 97-127, 2003.

Somma, R., Messina, A., and Mazzoli, S.: Syn-orogenic extension in the Peloritani Alpine Thrust Belt (NE Sicily, Italy): Evidence from the Alì Unit, C. R. Geosci., 337, 861-871, 2005.

Stewart, I. S., Cundy, A., Kershaw, S., and Firth, C.: Holocene coastal uplift in the Taormina area, northeastern Sicily: Implications for the southern prolongation of the Calabrian seismogenic belt, J. Geodynam., 24/14, 37-50, 1997.

Süzen, M. L. and Doyuran, V.: A comparison of the GIS based landslide susceptibility assessment methods: multivariate versus bivariate, Environ. Geol., 45, 665-679, 2004.

Tortorici, L., Monaco, C., Tansi, C., and Cocina, O.: Recent and active tectonics in the Calabrian arc (Southern Italy), Tectonophys., 243, 37-55, 1995.

van Westen, C. J.: Statistical landslide hazard analysis. In: Application guide, ILWIS 2.1 for Windows, ITC, Enschede, The Netherlands, 73-84, 1997.

van Westen, C. J., Rengers, N., Terlien, M. T. J., and Soeters, R.: Prediction of the occurrence of slope instability phenomena 
through GIS-based hazard zonation, Geol. Rundsch., 86, 404414, 1997.

van Westen, C. J., Rengers, N., and Soeters, R.: Use of geomorphological information in indirect landslide susceptibility assessment, Nat. Hazards, 30, 399-419, 2003.

van Westen, C. J., van Asch, T. W. J., and Soeters, R.: Landslide hazard and risk zonation - why is it still so difficult?, Bull. Eng. Geol. Environ., 65, 167-184, 2006.

van Westen, C. J., Castellanos, E., and Kuriakose, S. L.: Spatial data for landslide susceptibility, hazard, and vulnerability assessment: An overview, Eng. Geol., 102, 112-131, 2008.
Vecchio, A.: Analisi delle caratteristiche idrauliche del bacino idrografico del T. Giampilieri: valutazione del "rialzo idraulico" in sezioni ostruite (evento 1 Ottobre 2009), University of Catania, 2011.

Westaway, R.: Quaternary uplift of Southern Italy, J. Geophys. Res., 98, 21741-21772, 1993.

Yalcin, A.: GIS-based landslide susceptibility mapping using analytical hierarchy process and bivariate statistics in Ardesen (Turkey): Comparisons of results and confirmations, Catena, 72, 1-121, 2008. 